increased considerably, but two of the objects for which the Institute was founded, the education of medical officers of health and the treatment of patients, have been discontinued. Elementary education in bacteriology was soon afterwards adequately provided for by the medical schools, and the prophylactic treatment for hydrophobia, which was the particular treatment in view, was no longer required owing to the freedom of the British Isles from rabies.

The advantages which the Institute enjoyed from its association with Lister were, in the earlier days of its history, by no means confined to his guidance as chairman of its council. To the scientific staff he was always a colleague. Whatever the nature of the problem they were occupied with, they were sure of his sympathy, and his knowledge and critical insight were ever at the disposal of the humblest worker. During the latter years of his life, although no longer able to take an active part in directing its affairs, he did not cease to take a keen interest in the welfare of the institution he had been largely instrumental in founding, and he manifested his confidence in its continued usefulness by making it joint beneficiary with the Royal Society under his will.

\title{
Some Aspects of Lister's Scientific Work.
}

\section{By Prof. William Bulloch, F.R.S.}

$\mathbf{M}^{\mathrm{Y}}$ $\mathrm{Y}$ qualifications to write on certain aspects of Lister's scientific work rest on an acquaintance with his published writings. I have studied these critically by themselves and in relation to the writings on the same subjects by his contemporaries. For more than ten years I also had the great privilege of knowing Lord Lister in a manner which, considering the great disparity of our positions, I may say was almost intimate. As bacteriologist to the British Institute of Preventive Medicine I had to visit him as chairman almost weekly, to keep him in touch with the progress of the work in the antitoxin department. Even after I left the service of the Institute he frequently asked me to call upon him in connexion with scientific work in which he was interested. In this way I was a great deal in his company and, among the younger men of that time, probably saw more of him than any one else.

When I first knew Lord Lister he was sixty-eight, and I last saw him in 1909 when he was eighty-two years of age. Both then and since he impressed me as a great personality. He was deeply interested in all advances of medical knowledge and, although leading a very busy life, he strove to keep abreast of bacteriological literature, which was then pouring forth in an unbroken stream. I read through with him most of the complicated papers of Ehrlich and Bordet on hæmolysis. During the reading he would make many suggestions or criticisms which might clear up doubtful points. Finished with the work in hand, he would recur to his own work of early days and indicate the difficulties he had had and how he had overcome them. In a conversation we had on Oct. 23,1905 , he said to me-I wrote it down at the time: "If my works are read when I am gone, my papers on the pigmentary changes in the frog and on the early stages of inflammation will be the ones most highly thought of." These were not the mumblings of senility, for he was then intellectually clear and alert. I took it to mean that he wished to be considered as a scientist rather than a surgical craftsman.

In estimating Lister's scientific work it is essential to remember that he had no properly equipped laboratory as we understand the term to-day. There were none such, or but few at the time. His laboratory was his study in his private home, and perhaps the best of his scientific work was that done in 11 Rutland Street, Edinburgh, during his first stay in the northern capital. His principal work on antiseptics was done during the Glasgow period, while his bacteriological work was begun and largely completed in his second Edinburgh period when he resided at 9 Charlotte Square.

The hours for Lister's scientific work were early in the morning and far into the night following a harassing day of active surgical work in private practice, or in the wards, operating theatre, and class-rooms of the Edinburgh Infirmary. He performed all his appointed duties in a most conscientious way, and he undertook his experimental work so that he might speak with first-hand knowledge on the themes which he had to teach. Many of the problems he felt impelled to investigate were obscure and complicated, but of the greatest practical importance. Some were not capable of solution then, and others have not yet been definitively cleared up. I refer in particular to his work on the coagulation of the blood and on the early stages of inflammation.

The coagulation of the blood has at all times excited wonderment, and the theories to explain it have been innumerable and are still being brought to light. In Great Britain notable advances were made in the eighteenth century by William Hewson, who unfortunately died of sepsis from a wound before he was thirty-five. In his short life he made, however, many discoveries. He proved that the red corpuscles were biconcave discs; he described their arrangement in masses like piles of money, an observation extended in 1827 by Lord Lister's father in association with Dr. Thomas Hodgkin. Hewson also clearly noted the existence of the white blood corpuscles and performed a large number of experiments on blood coagulation, although he never quite cleared up the mystery of its nature. His successors in the nineteenth century were not more happy. Coagulation of the blood was early studied by Lister. The problem was constantly before him in connexion with intravascular clotting

$$
\text { No. 2997, VoL. 119] }
$$


and the occurrence of putrefaction and secondary hæmorrhage in wounds. The prevailing theory was that of B. W. Richardson, and referred the clotting to the escape of ammonia, which was believed to hold the coagulative elements, normally, in solution.

In a long series of masterly experiments Lister showed that this ammonia theory was untenable. He clearly saw the need of separating the nature of coagulation from the cause, and while baffled with the former he revealed by his experiments that the latter-the cause of coagulation-is really due to the influence exerted on the blood by the contact, even momentarily, of ordinary matter of some kind. He considered that this contact brings about a reaction between the solid and fluid constituents of the blood so that the corpuscles imparted to the liquor sanguines the disposition to clot. As regards the cause of blood coagulation, it cannot be said that we have materially advanced during the seventy years since the publication of Lister's paper.

Another basic pathological process which Lister examined was inflammation. The extraordinary changes which we call inflammation have at all times attracted attention, and the theories intended to explain it constitute a large part of the history of medical doctrines. What is the real nature of the process which we call inflammatory and which results from the application of an irritamentum to the body? When Lister began his studies on inflammation, great advances on the older doctrines had already taken place. In England particularly, the science of experimental pathology was in process of rapid growth. The older pathological anatomy so ably created by Morgagni was developed well by the French, among whom the names of Bayle, Portal, Laennec, Bretonneau, Chomel, and Cruveilhier will be brought to mind. Students went from Great Britain to study pathological science in France.

At the beginning of the nineteenth century Edinburgh was a great nursery of medical talent, and many of her graduates migrated across the border to attain fame in the arenas of the south. We all remember with pride the names of Charles Bell, Richard Bright, Thomas Addison, Thomas Hodgkin, C. J. B. Williams, Marshall Hall, William Sharpey, and the peculiarly able if eccentric Wharton Jones. Their work was advanced by the experimental work of Augustus Volnay Waller and of the little-known but successful worker William Addison. Lister had both Sharpey and Wharton Jones for his teachers. The margination of the leucocytes in the inflamed vessels was taught by C. J. B. Williams, and W. Addison about 1842 and Waller (1846) rediscovered the process of emigration of the leucocytes, which had been previously described by Dutrochet in 1827. Wharton Jones summed up in most critical fashion all the work down to 1846, and himself gained the Astley Cooper prize in 1850 for his splendid essay on the phenomena of inflammation.

When, therefore, Lister began to work at the pathology of inflammation he was traversing ground already trodden. He realised, however, that much that had been done concerned the later stages of the process, whereas the real essence of inflammation was most likely to be found by the study of the earliest stages. He worked chiefly with the frog's web and the bat's wing, and took elaborate precautions that at first the parts should be in a perfectly normal condition. By the application of irritants he then passed to the study of what was pathological. Among the phenomena which he particularly investigated may be mentioned the aggregation of the red blood corpuscles, their increased adhesiveness, and the structure of the arterioles and capillaries. $\mathrm{He}$ found that the capillaries alter in calibre, but referred the variation to something inherent in their elasticity. While admitting the phenomenon of contractility in the capillaries, modern workers have not accepted his explanation. Lister regarded irritants as acting in a twofold manner. The primary effect was a dilatation of the vessels brought about by the influence of the nervous system and not limited to the locus of the irritant. The secondary effect, on the other hand, was the direct result of the irritant acting on the tissues in consequence of which the blood becomes altered physically. The red discs become more adhesive, they accumulate in masses and may bring about the condition of stasis.

Strange to say, Lister made no reference to diapedesis of leucocytes, and probably missed it altogether. Waller's discovery of 1846 had left so little impress at the time that when diapedesis was described in detail in 1867 by Cohnheim, it was regarded as something altogether new. Previous to Lister's work, the advanced changes in inflammation had been observed and very fully described by Wharton Jones, but it is to Lister's credit that he examined it from a new viewpoint and discussed its significance more than his predecessors had done. He was, however, surpassed by Cohnheim in his classical work in 1867.

When Lister embarked on his extended researches on wound complications and the cause of suppuration, his experimental inquiries on blood and inflammation were a great help to him. He was groping unaided for the causes of suppuration, but light was beginning to peer through the darkness. This was early in his Glasgow term. In 1865 his attention was directed by a colleague to the work which had been done on fermentation and putrefaction by Pasteur, and this came to him as a revelation. Almost immediately he grasped the significance of the Frenchman's work for surgery. Ten years later (1875) he specifically tells us that the work of Pasteur " long since made me a convert to the germ theory, and it was on the basis of that theory that I founded the antiseptic treatment of wounds in surgery."

Although Lister constantly stated his indebtedness to Pasteur, it is, I think, a vulgar error to regard him as a mere copyist of his great French contemporary. So early as 1861 , and before he knew Pasteur's results, he-was getting near the truth about suppuration, and later on he advanced

No. 2997, VoL. 119] 
beyond the point where Pasteur had led him. No doubt Pasteur revealed to him in a more concrete form what he had dimly foreseen himself, and from then onwards he was ardent in the pursuit of bacteriology. The time would be the early 'seventies, when the study of microbes had not emerged as a definite science. There were at the time two conflicting views. One of these, supported by Ferdinand Cohn, the botanist of Breslau, held that bacteria, like other plants, had a constancy of form which rendered them capable of division into genera and species. According to the other view, there was no morphological constancy, but rather a pleomorphism, whereby one and the same bacterium could assume different forms. If this were true, attempts to cultivate or to separate them on morphological grounds were doomed to failure.

In his earliest work on the subject in 1873 , Lister's observations led him to support the pleomorphic theory, and it will now be admitted that he suffered shipwreck upon it when he stated that Ehrenberg's and Cohn's morphological classification was "entirely untrustworthy." Lister's mistake was one which at the time was made by a great many others and tends to indicate the extraordinary pitfalls which beset the path of the earlier bacteriologists. In his life of Lister, Godlee has published an interesting correspondence which passed between Lister and Pasteur on the subject of change of form among bacteria. Pasteur clearly saw where Lister had erred and advised him to repeat his observations with additional technical precautions. This Lister did, and profiting by his new experience he became one of the foremost bacteriological technicians of his time. So imbued was he with the spirit of high ideals that instead of covering up his tracks he handsomely withdrew his error. "Next to the promulgation of truth," he said, "the best thing I can conceive that a man can do is the recantation of a published error." This sentiment was almost identical with that given to us nearly two thousand years ago by Celsus, who, however, added that such a confession is suited only to a great genius whose splendour is such as to survive the sacrifice, especially in the performance of a task which is to be handed down for the benefit of posterity as a beacon of truth to warn them against similar errors.

From the theory of Cohn and Pasteur it was to be presumed that bacteria might in some way be separated from each other and cultivated in a pure state. The great mycologist, Brefeld, had emphasised the importance of raising such pure strains or cultures from one single germ or cell of a fungus. Following in his wake, Lister was the first to isolate a pure culture of a bacterium. By perfect bacteriological technique involving a complete understanding of the problem, he succeeded in isolating a pure culture of a microbe, Bacterium lactis, which is the cause of lactic-acid fermentation in milk. He grew this microbe in sterile milk and raised a pure strain, constant morphologically and physiologically, from a single cell by a series of dilutions carried out with an ingeniously constructed syringe of his own invention. No one can deprive Lister of the merit of having first isolated bacteria in pure culture outside the body. The year was 1877. Lister also introduced the methods of hot-air sterilisation which are in vogue today. His long paper on lactic fermentation is a classic, and a model of what a scientific research should be.

Like Pasteur, Lister had the supreme faculty of seeing as if by instinct the exact experiment needed to clear up a point of doubt. All his scientific work bears witness to this, but I may refer to one other instance of it. In two or three experiments which he did on the fate of catgut implanted in the tissues, he got out all the essential facts in 1869, and later attempts of others in more than three hundred papers down to 1927 have, literally speaking, neither added to nor subtracted from anything which he taught us sixty years ago. He was a master of the experimental method-a rare and precious gift which, the Abbate Spallanzani truly said, " has always been confined and always will be confined to.the few."

\section{Obituary.}

Prof. Carl Runge.

W ITH the death, on Jan. 3, 1927, of Prof. Carl Runge, of the University of Göttingen, in his seventy-first year, there has passed away an eminent mathematician and a friend to several generations of English-speaking students in Germany.

Runge, whose mother was English, was born in Bremen in 1856 and was educated at Munich and Berlin. In 1886 he was called to the Technical High School at Hanover, where he remained until 1904, when he moved to a professorship at Göttingen in response to an invitation from Klein. Coming in early life under the dominating influence of Weierstrass and Kronecker, it was not unnatural that his first work should be in the field of function theory and algebra, but the urge towards the practical, which directed much of his later work, was soon apparent. Many of his lectures at Columbia University, where he went as an exchange professor in 1909-10, deal with this aspect. At Hanover, as a mathematician in an engineering environment, he had perforce to devise ways and means of adapting methods of mathematical analysis to the practical. Many of his numerical and graphical methods, numerical integration, solution of differential equations and Fourier analysis are now commonplace in engineering training. In this respect his influence on German teaching methods was rather similar to that of Perry in Great Britain. Wherever possible he played an active part in actual practical work, as for example when he assisted in a large geodetic survey, and his appreciation of real problems

No. 2997, VoL. 119] 